\title{
Is Apocalyptic Kiev Still Apocalyptic Kiev in English Translations of Mikhail Bulgakov's Novel The White Guard?
}

\section{Abstract}

The White Guard, an epic narrative on the Russian Civil War, is also an urban novel based on the author's personal experiences in Kiev during the tumultuous years of the Revolution and Civil War Following the traditions established by F. Dostojevsky and I. Bunin, Bulgakov introduces the City, Kiev, not only as the setting of the novel, but as one of the main protagonists - one that changes, develops and takes part in the lives of the other protagonists. The city is thus transformed into a psychological dimension where the violence of war and the mental world of the characters are reflected onto the city itself. As intertextuality is one of the main characteristics of Bulgakov's style, he employs numerous allusions to the Book of Revelation when describing the events in the novel and when constructing the image of the city. Following his typical ambivalence, Bulgakov depicts Kiev as a place of beauty, light, and happiness, similar to the New Jerusalem from the Revelation, and as a place of chaos, promiscuity, and violence, like that of the apocalyptic Babylon. The city is also divided into two zones: the Civil war zone, dangerous and violent, and a domestic zone, which represents safety, family and old prerevolutionary values. The novel has been translated into English three times: by Michael Glenny (1971), Marian Schwartz (2008) and Roger Cockrell (2012). This unique material offers thorough insight into translation shifts, not only from a synchronic, but also from a diachronic perspective. In our research, we focused on the translation strategies used when rendering apocalyptic allusions employed by the author to describe the City and assessed some of translation choices. We wonder if and to what extent the translators 
recognized and adequately transferred the original allusions and the ambivalent, apocalyptic and complex world of Bulgakov's City.

Keywords: allusion, Bulgakov, Revelation, The White Guard, translation

\section{Introduction}

Bulgakov's first semi-autobiographical ${ }^{1]}$ novel, The White Guard (Белая Гвардия), ${ }^{[2]}$ serialized in 1925, tells the story of the aristocratic Turbin ${ }^{[3]}$ family plunged into the chaotic civil war that erupted in the Ukraine in the wake of the Russian Revolution. In the context of this family's personal loss and the social turmoil surrounding them, Bulgakov creates a brilliant picture of the existential crises brought about by the revolution and the loss of social, moral, and political certainties. In this naturalistic narrative, Bulgakov confronts the reader with the bewildering cruelty of war, which destroys the fundamental grounds of normal life.

Bulgakov's realistic and sympathetic portrayal of the motives and behavior of the supporters of the White cause was strikingly unusual for the official literary discourse, which exaggeratingly glorified the deeds of the Red Bolsheviks' Army. Substantially rewritten and complete, the novel was first published in Paris in 1927 (the first part) and 1929 (the second part) by Concorde publishing house, but given its

controversial subject matter, it was not published in the Soviet Union until 1966.

The White Guard is also an urban novel based on the author's personal experiences in Kiev during the tumultuous years of the Revolution and Civil War (1918-1921). The novel takes place in Kiev, in December 1918, a time of turmoil and suffocating uncertainty as the Bolsheviks, Socialists, and Germans fight for control of the city. At the beginning of the narrative, Kiev is in the hands of German troops, which eventually withdraw, leaving the city under siege by Simon Petlura, a socialist leader of the Ukraine's unsuccessful fight for independence following the Russian revolutions of 1917, and his army. Young cadets who protect the city are brutally slaughtered, but Petlura's rule lasts for only forty-seven days. Afterwards, the Soviet army recaptures Kiev.

Though Bulgakov intentionally uses only the noun, "the City," throughout the narrative, the unnamed, urban locality is clearly Kiev and resembles both New Jerusalem, a place of beauty, 
light, and happiness, and apocalyptic Babylon, a place of chaos, promiscuity, corruption, decay, and violence. As intertextuality is one of the author's main stylistic features, Bulgakov employs numerous allusions to various passages from the Book of Revelation ${ }^{[4]}$ when describing events in the novel and constructing the theme of the City as a setting of apocalyptic events. By alluding to various apocalyptic images and symbols, such as the apocalyptic beast, horsemen, a snowstorm, and the red star, the author establishes his perception of the Russian revolution as a destructive, barbarian force that ripped Russian life apart. Identifying and transferring these allusions are crucial to recognizing the apocalyptic prophecy as one of the key pretexts of Bulgakov's novel[5] There are numerous reasons for retranslations. A general western interest in Bulgakov as a persona non grata in the Soviet Union, or the mysterious aura of a long-suppressed manuscript may have helped, but a total of three competing English versions of the novel have appeared to date, as follows: Michael Glenny (1971), Marian Schwartz (2008) and Roger Cockrell (2012).[6] This material offers insight into translation shifts not only from a synchronic, but also from a diachronic perspective.

Considering the uniqueness of this material, we found it surprising that no comparative research of all three English translations has been done so far (to our knowledge). In considering these versions, we wished to analyze translation strategies used when rendering the City's textual representation, focusing on translation adequacy when rendering allusions to the Book of Revelation and the author's unique personification of the City.

The apocalyptic vision of reality does not appear in The White Guard alone; allusions to the Book of Revelation appear in all of Bulgakov's subsequent works, emphasizing the writer's eschatological perception of Russian contemporary history. Hence, drawing on existing theories in the field of translation, the paper seeks to develop a conceptual framework suited specifically to the analysis of allusions to the Book of Revelation, which may have wider applicability when analyzing the existing English translations and retranslations of Bulgakov's other works, such as The Flight, A Heart of a Dog, The Fatal Eggs, Adam and Eve, etc.

\section{Theoretical Background}


One of the most important aspects of allusions to be considered is their sources and recognizability. Typically, allusions arise from history and literature (Leddy 112), but they also may arise from topical events, music, sculpture, and paintings (Perri 295) or other cultural texts in general (television, cinema, comics). Typical to all sources of allusions is that they are simultaneously potentially known and limited to certain subgroups (see Leddy 112). Ben-Porat maintains that it is usually possible to read and understand the alluding text without activating the allusion, but this obviously means losing the enriching connotations (115). Still, part of the pleasure of recognizing and understanding allusions is suspecting that they are not equally clear to others. In other words, as Susan Stewart notes, allusion is about membership (1136). In order to understand the allusions, readers must first recognize them. It is this aspect of allusion that ultimately makes it different from plagiarism, which is intended to remain hidden (see Pucci 39 and Pasco 9). Recognizing allusions depends on the reader's familiarity with the cultural texts that are typically evoked. Recognizability is a tricky issue with respect to translation, as the translator is the first and, presumably, competent reader and is expected to recognize an allusion and then successfully render it.

As the current analysis focuses on translation of allusion, we used Leppihalme's 1997 research of allusion translation. Leppihalme divided allusions into proper names (in which a name is mentioned) and key phrases (in which there is a phrase that refers to a name) and suggested a set of diverse strategies for translation of these two types. Proper name allusions can be about real-life and fictional figures, international names of entertainers or politicians, famous names of past generations, writers, painters, and so on. As for key-phrase allusions, Leppihalme believes that the Bible is the most common single source of key-phrase allusions. Among other sources, the researcher mentions nursery rhymes and children's tales, songs, well-known films and topical television programs, political slogans, commercial product slogans, various catch-phrases, clichés and proverbs and various popular beliefs, assumptions and stories (Leppihalme 84).

Naturally, allusions are culture-bound and the extent to which they are comprehensible across cultures and language barriers varies a great deal. The sources of allusions - history, literature, cinema, and television, to mention some of the most important sources - are rarely understandable beyond their original culture. Leppihalme also believes that recognition of the source of key-phrase 
allusions strongly depends on familiarity. If the reader has heard a phrase repeatedly since childhood, read it in books, heard it in churches, at school, in songs, in films and television programs, etc., then s/he will easily recognize it and its sources (Leppihalme 85).

Translating allusive texts is complicated by two factors: firstly, it is probable that since the connotations of the allusions are not activated in the reading process, the readers of the translation cannot understand much of a number of allusions, even if the source is given. Secondly, the translation readers are usually not a homogenous group, and some of them will probably understand and enjoy allusions if they are given the chance but will resent them being written down in the form of additional explanations (Leppihalme 110).

According to Leppihalme, it is necessary that the translator recognize the allusions in the text s/he wants to translate and pause to find the appropriate strategy for translating them. It is possible for the translator to keep a proper name unchanged, but a key-phrase allusion usually needs a change in wording. Leppihalme also believes that translation strategies form a hierarchy along the lines of the minimax principle, proposed by Levy (1967), which is a minimum effort with a maximum effect. It can be claimed that a familiar allusion requires less thought than an unfamiliar one, while an allusion of great significance for the interpretation of the text requires more attention (Leppihalme 185). The author also argues that translators should pay attention to the fact that they are cultural mediators, who must use their bicultural competence to identify and analyze the function of allusions in the source text and find the best translation strategies to serve target text readers. In our research, we will focus on translation strategies suggested for key-phrase allusions:

(a) Use of a standard translation

(b) Minimum change / literal translation

(c) Addition of extra-allusive guidance (including typographical means)

(d) Footnotes, endnotes, forewords and other additional explanations outside the text itself

(e) Simulated familiarity, internal marking (marked wording or syntax)

(f) Replacement by preformed target-language item

(g) Reduction to sense (making the connotations overt but dispensing with the alluding words) 
(h) Recreation using a variety of techniques

(i) Omission (Leppihalme 84).

In addition, Leppihalme suggests that it is possible that the allusion be left untranslated, that is, appearing in the target text in its source-text form. The use of a standard translation is obviously only a choice if one exists, and it may occasionally be identical to the minimum change translation. Recreation is a demanding strategy, so it is not very likely to come up in the current analysis. Omission is placed last in Leppihalme's list for two reasons: first, it may be effortless, but it does not result in a maximum of effect (130), and second, omission is the last resort - permissible only when everything else fails (121).

\section{Comparative Analysis of English Translations: Key-phrase}

\section{Allusions}

Our analysis of allusions in The White Guard is based on allusions to the apocalyptic prophecy as presented in the Book of Revelation ${ }^{7]}$ and, more precisely, to the parts relating to the depiction of New Jerusalem and Babylon. In what follows, we will examine thematic key-phrase allusions to the Book of Revelation ${ }^{[8]}$ that contextualize the City and discuss how and if these allusions have been rendered in the translations. We will also consider whether the preferred strategy makes it possible for readers to identify the connotations of the allusions. The first question that naturally arises is that it is debatable how familiar the Book of Revelation is to present-day readers. Presumably, cultural products (e.g. films, songs, and paintings) embedded certain key elements such as the Whore of Babylon, Apocalyptic Beast, The Day of Judgement, or Apocalyptic Horses in the public consciousness, and these are hence often used allusively. However, we assume that there are less familiar textual elements such as details of New Jerusalem. It is impossible to speculate about how familiar English readers are with the Book of Revelation or to what extent the translators recognized apocalyptic allusions in the text. Hence, we suppose that some key-phrase allusions, such as the reference to the number of the apocalyptic beast, the Red star, sharp sword, gardens, and Judgement day are more familiar and evoke immediate association in the translators and readers, while others, such as precious stones, pearls, light, glass, and other features of New 
Jerusalem may be less obvious. In our opinion, the latter group of allusions would pose more problems for translators.

Before turning to the analysis of apocalyptic allusions, our first observation is that all translators consistently used a capital letter when the author was referring to the City. Petrovsky points out the "strangeness" of Bulgakov's setting, as "[t]here is no Kiev - there is only city (in the protagonists' speech) and City in the authors' speech" (Petrovsky 270). By introducing this device, Bulgakov denies Kiev from being the only possible setting of the novel but alludes to other cities such as Rome, the only city in the European tradition that is referred to as Urbs (City), Jerusalem, and biblical Babylon. Petrovsky claims that Bulgakov intentionally introduces the "Eternal City" as an eschatological, mythological place of not only historical but also mysterious events. While this element was preserved in all translations, they differ in their (not) offering of explanations for the author's decision. Schwartz's translation is accompanied by an introduction in the form of a historical essay by E. Dobrenko in which the historical context, the significance of the setting, and the main motifs are thoroughly explained. A professional and thoughtful insight into the novel also explains the author's choice to use only 'the City' for Kiev. In Cockrell's translation, we find a footnote that explains that "Bulgakov refers to the Ukrainian capital Kiev throughout The White Guard as 'the City'” (267), while Glenny's translation does not offer any explanation.

The next observation is that most allusions relating to the City occur in the opening chapters of the novel, in which Bulgakov establishes the City as the main setting for the upcoming apocalyptic events. Thus, in the opening chapter, Bulgakov depicts the City in a dual dimension. Kiev is a wondrous beautiful city-as-recollection, a daydream, and a legend, sparkling and marvelous. Yet from the outside, it is dominated not only by implacable sunlight, peace and tranquility, but also by the gloomy apocalyptic feeling of upcoming danger. This perception is channeled through the narrator's own perspective and through the embodied viewpoints of one or more characters.

Bulgakov: ... несмотря на то, что на подступах к Городу - коварный враг, который, пожалуй, может разбить снежный, прекрасный Город и осколки покоя растоптать каблуками. (11) 
Glenny: ... despite the fact that out there, on the roads leading into the City, lay the cunning enemy, poised to crush the beautiful snowbound City and grind the shattered remnants of peace and quiet into fragments beneath the heel of his boot. (13)

Schwartz: ... even though there was a cunning enemy on the approaches to the City who might very well smash the beautiful snowy City and trample the shreds of tranquillity under his heels. (12)

Cockrell: ... despite the fact that, at the gates to the City, there was a cunning enemy capable, perhaps, of destroying its snow-covered beauty and trampling on the rubble. (15)

Bulgakov tends to give the reader a sharp delineation between the City as an oasis of peace and beauty, a domestic zone that represents safety and is associated with the pre-revolutionary lifestyle and values, and the alien zone of the City's outskirts and countryside, the steppe, as the embodiment of barbarianism, violence, and danger. What should be clear from this short passage is that the City is in danger, surrounded by purely demonizing forces. On the other hand, Bulgakov introduces the City as a beautiful, fragile, crystal-like place, establishing a key link with New Jerusalem. With the verb разбить/to break, combined with осколки/shards, the author employs an allusion to New Jerusalem, which is depicted as being made of glass:

Revelation: And her light was like unto a stone most precious, even like a jasper stone, clear as crystal. (21.11)

The wall itself was built of translucent stone, while the city was of purest gold, with the brilliance of glass. (21.18)

The street of the city was purest gold gleaming like glass. (21.21)

The comparison to glass is crucial for the successful recognition of this allusion. All three translators used different verbs, employing the strategy of reduced meaning, to render the original verb разбить, which means "to shatter/to break," and in Russian is used primarily when referring to smashing glass or ice. Cockrell's option "to destroy" is perhaps less successful, as it does not transfer the original's connotation of breaking glass. The noun осколки (shards) intensifies the 
image of the City as vulnerable and fragile - as easily broken as glass. It is interesting that none of the translators opted for the strategy of literal translation with the word 'shards'. The alternative translations with reduced meaning seem to fail in conveying the right connotations based on comparing the City to crystal and glass as in the Book of Revelation. Schwartz's option "shreds" would be more appropriate for referring to paper or paper-like material and maybe thin fabric, while "remnants" are usually garments, fabric and sometimes flesh but never glass. Cockrell's "rubble" also does not transfer the original meaning as it is commonly used for concrete, blocks, bricks, and stone. Another significant omission in Cockrell's translation is the noun покой/peace, which was rendered by other translators as "tranquillity" and "peace." Schwartz's choice of "tranquillity" also implies serenity, an important connotation attached to the Russian original, while "peaceful," though correct, is further from the original meaning.

In the next example, Bulgakov refers to the City's gardens, while constructing the topography of the setting:

Bulgakov: Сады стояли безмолвные и спокойные, отягченные белым, нетронутым снегом. И было садов в Городе так много, как ни в одном городе мира ... сады красовались на прекрасных горах, нависших над Днепром ... (41)

Glenny: The gardens lay silent and peaceful, weighed down with white virgin snow. And there were more gardens in the City than any other city in the world ... The beautiful hills rising above the Dniepr were made lovelier by gardens that rose terrace-wise ... (54)

Schwartz: The gardens were silent and peaceful weighed under by untouched white snow. There were more gardens in the City than in any other city in the world ... The gardens stood out vividly on the beautiful hills that hung above the Dniepr...

Cockrell: Covered in white, virgin snow, the parks stood silent and peaceful - and there was no city in the world that had as many parks as the City ... The beauty of the hills above the Dniepr was enhanced by many lovely parks. (48)

Terrace-like gardens are one of the most significant landscape marks of Bulgakov's City and a distinctive allusion to the Semiramide Hanging Gardens of Babylon and the Garden of Eden ${ }^{[9]}$ The 
ambivalent depiction of the City as resembling both Paradise and New Jerusalem, the eternal place of beauty and light, and the apocalyptic Babylon, destined to fall, is reconstructed throughout the narrative. In this case, Cockrell used the strategy of reduction by opting for a different noun, which makes the meaning less overt, and dispensing with the allusive key phrase. It is also difficult to imagine parks rather than terrace gardens lying on the hills. Schwartz and Glenny used the strategy of literal translation. It should be noted that all three translations followed Bulgakov's original intention to distinguish clearly between the City and other cities through the use of capitalization.

At the beginning of the fourth chapter, Bulgakov employs another key-phrase allusion to New Jerusalem by comparing the City to a pearl:

Bulgakov: ... когда Город проснулся сияющий, как жемчужина в бирюзе, ... (48)

Glenny: ... when the City awoke looking like a pearl set in turquoise

Schwartz: ... when the City awoke, shining like a pearl in turquoise

Cockrell: ... when the City had woken up to greet the morning, glittering like a pearl in turquoise ...

Revelation: And the twelve gates were twelve pearls, with each gate consisting of a single pearl.

Though all translators followed the source text closely by employing the strategy of literal translation, keeping the original allusive comparison to a pearl intact, a minor shift occurred when rendering the original бирюза, which refers only to a precious stone. All three translators used the adjective "turquoise," which may also refer to the color. Glenny's generalized choice of the verb "to look" does not transfer the connotations of the original, more expressly poetic, adjective associated with shining or glittering.

A comparison to precious stones used to decorate the wall of New Jerusalem also occurs in the following passage: 
Bulgakov: Цепочками, сколько хватало глаз, как драгоценные камни, сияли электрические шары ... (44)

Glenny: As far as the eye could see, like strings of precious stones, hung the tows of electric globes suspended high from the elegant curlicues of tall lamp-posts

Schwartz: Chains of electric globes stretching farther than the eye could see hung high on the hooks of long grey poles, shining like precious stones

Cockrell: Electric lights shone like precious stones, perched high on curlicues on the tall lampposts that stretched into the distance as far as the eye could see

Revelation: The foundation stones of the wall of the city were fashioned out of every kind of precious stone. (21.19)

All translators opted for the strategy of literal translation. As in previous examples, it is difficult to infer from the context that New Jerusalem is alluded to without prior knowledge of similar references regarding Kiev in Bulgakov's other works (e.g. the short story "Kiev-gorod") and extra guidance. It was impossible for the translators to slip in any explanations without creating clumsy additions (e.g. "like precious stones of New Jerusalem").

In the following example, Bulgakov employs another typical ambivalence, depicting the City not only as shining, peaceful and glorious but also as chaotic, strange, and hectic. A City of turbulent changes and violent forbidden pleasures. A City filled with desperate refugees. A City destined to fall like apocalyptic Babylon:

Bulgakov: И вот, в зиму 1918 года, Город жил странною, неестественной жизнью, которая, очень возможно, уже не повторится в двадцатом столетии. (43)

Glenny: In that winter of 1918, the City lived a strange unnatural life, which is unlikely ever to be repeated in the twentieth century. (56) 
Schwartz: So here it was, the winter of 1918. The life of the City was bizarre and unnatural, a life that might very well never be repeated in the twentieth century. (53)

Cockrell: And now, in the winter of 1918, the City lived a strange, unnatural life, a life that very probably will never be repeated in the twentieth century. (49)

In the following longer passage, Bulgakov's equine and equestrian key-phrase allusions are well marked to suggest the presence of some other code or subtext.

Bulgakov: Бежали седоватые банкиры со своими женами, бежали талантливые дельцы, оставившие доверенных помощников в Москве, которым было поручено не терять связи с тем новым миром, который нарождался в Московском царстве, домовладельцы, покинувшие дома верным тайным приказчикам, промышленники, купцы, адвокаты, общественные деятели. Бежали журналисты, московские и петербургские, продажные, алчные, трусливые. Кокотки. Честные дамы из аристократических фрамилий. Их нежные дочери, петербургские бледные развратницы с накрашенными карминовыми губами. Бежали секретари директоров департаментов, юные пассивные педерасты. Бежали князья и алтынники, поэты и ростовщики, жандармы и актрисы императорских театров.

Вся эта масса, просачиваясь в щель, держала свой путь на Город. (43)

Scattered throughout the chapter are key-phrase allusions not to New Jerusalem but to the apocalyptic Babylon, such as refugees (беженцы), nightlife (ночная жизнь), theatres (театры), casinos (игорные дома), prostitutes (развратницы, проститутки, кокотки), homosexuals ( педерасты), drugs (кокаин), and other images that allude to biblical mortal sins. By depicting the life of the City as chaotic and promiscuous, Bulgakov intentionally strips away tranquil, heavenly, idealistic coloration. His City not only resembles a place of beauty and peace similar to New Jerusalem but also apocalyptic Babylon. All these textual features were preserved in the English translations by the strategies of literal translation. The only difference occurred when rendering the term беженцы (refugees), who streamed into the City. Surprisingly, only Glenny used the literal translation "refugees" (56), while Cockrell and Schwartz opted for "newcomers" (49) and "arrivals" (56) respectively, which have different connotations and do not employ the idea of leaving one's native place by force, in this case because of war. 
In the opening passage of chapter five, more key-phrase allusions are used: two знамения/omens (48), a terrible explosive sound and the murder of the general of the German army. Both omens signify the upcoming apocalyptic catastrophe, when the City will be taken by Petlura and his army. Cockrell (55) and Schwartz (61) opted for the noun "sign" to translate the Russian знамение, while Glenny decided on a literal translation with "omen" (63). Glenny's choice of "omen" is semantically more accurate, as "sign" is usually an indicator that can be good or bad, while "omen" is an indicator with clear negative connotations attached.

Another apocalyptic allusion in the same chapter is the release of the main apocalyptic threat to the City, Petlura, from the cell numbered 666. This number is mentioned in the Book of Revelation: "Let him that has understanding count the number of the beast: for the number of man; and its number is six hundred sixty-six." (13.18) All translators, Glenny (67), Cockrell (58), and Schwartz (65), kept the original number without providing any intratextual or extratextual explanations. This allusion is often used in films, music, and other cultural discourses and perhaps is easy to recognize, even for those readers who are unfamiliar with apocalyptic prophecy.

In the second part of the novel, Bulgakov focuses on the short siege, the fight for the City and upcoming events. As the setting is thoroughly established in the opening chapters, references to the City are less common in the second part of the narrative. One of the few allusions to the Book of Revelation appears in the nineteenth chapter, which depicts the end of Petlura's "reign" in the city:

Bulgakov: Пэтурра. Было его жития в Городе сорок семь дней. (237)

Glenny: Petlyura. His days in the City numbered forty-seven. (304)

Schwartz: Petlurra. He had a life in the City of forty-seven days. (291)

Cockrell: Petlurra. His sojourn in the City has lasted for forty-seven. days (249)

Even without possessing any knowledge about the Book of Revelation, it is easy to recognize the 
biblical style in the sentence, specifically in the word order, which all translators successfully transferred.

Finally, at the end of the novel, two more apocalyptic allusions occur in reference to the City. The first is the falling star of Mars, which explodes and falls. The falling star is mentioned several times in Revelation:

Bulgakov: И в ту минуту, когда лежащий испустил дух, звезда Марс над Слободкой под Городом вдруг разорвалась в замерзшей выси, брызнула огнем и оглушительно ударила.

Glenny: ... the planet Mars suddenly exploded in the frozen firmament above the City ... (316) Schwartz: ... the star of Mars suddenly exploded in the frozen heights ... (302)

Cockrell: ... the star of Mars in the frozen heights above the outskirts of the City suddenly exploded ... (258)

Revelation: The stars in the sky also fell to the earth, as when a fig-tree, upon being shaken by a gale of wind, casts its unripe figs to the ground. (6.13)

The third angel blew his trumpet, and a great star fell from heaven, blazing like a torch, and it fell on a third of the rivers and on the springs of water. (8.10)

The fifth angel blew his trumpet. I saw a star, that had fallen down from Heaven to earth, and he was given the key to the fathomless Pit. (9.1)

Mars throbs with threatening life, and now appears as a distinctly Bolshevik planet. Thus, the novel ends with the suggestion of a new permanence to replace the illusory, mundane peace represented by the symbols and leitmotifs of the first chapter. The Bolsheviks' forces, which free the City, do not mean salvation, but merely announce the beginning of another cycle of apocalyptic events. Glenny's modified rendering using a reduced meaning of the original "star" with "planet" weakens Bulgakov's allusions, as Revelation features a star and not a planet. It also destroys an allusion to the red star as a symbol of Bolshevism. Schwartz and Cockrell used literal translation. 
The final allusion is St. Vladimir's cross, which transforms into a sword at the end of the novel and becomes an apocalyptic sign of the upcoming Judgement day and another apocalyptic catastrophe. As Bulgakov clearly sympathized with the White cause and often referred to the October revolution and bolshevism as disasters, in his perception, the armed Bolsheviks do not mean salvation for the City, but rather, announce greater horrors that lay ahead.

Bulgakov: Над Днепром с грешной и окровавленной и снежной земли поднимался в черную, мрачную высь полночный крест Владимира. Издали казалось, что поперечная перекладина исчезла - слилась с вертикалью, и от этого крест превратился в угрожающий острый меч. (242)

Glenny: Above the bank of the Dnieper, the midnight cross of St Vladimir thrust itself above the sinful, bloodstained, snowbound earth toward the grim, black sky. From far away it looked as if the cross-piece had vanished, had merged with the upright, turning the cross into a sharp and menacing sword. (323)

Schwartz: Above the Dnieper, Vladimir's midnight cross rose from the sinful, bloodied, snowy earth to the black and gloomy heights. From a distance its cross bar seemed to disappear and merge with its vertical, transforming the cross into a sharp, menacing sword. (309)

Cockrell: above the river Dnieper, and above the sinful, bloodstained and snow-covered earth, loomed the dark, sombre mass of the midnight cross of St Vladimir. From a distance, it seemed as if the crosspiece had merged with the vertical and had disappeared, transforming the cross into a sharp, threatening sword. (265)

Revelation: Out of His mouth there comes a sharp sword with which to strike the nations. (19.15)

All translators rendered the original's allusion literally, the difference occurring only in the use of the adjective "threatening" instead of "menacing" in Cockrell's translation, which does not have any significant impact on the recognition of the allusion.

\section{Conclusion}


Retranslations may be motivated by a wish to improve on or modernize previous translations (they can also be produced without any awareness of a preexisting translation, but the translators dealt with are unlikely to have been in this position). The claim that the subsequent translation is likely to bring significant improvement as compared to previous translations is hard to verify, however, especially because the meaning of "improvement" is vague. For this reason, the aim of the research was merely to assess the strategies used by various translators and hence the degree of proximity to the original. The results of our limited testing demonstrate that in all examples included in the analysis, the primary strategy of minimum change for key-phrase allusions was literal translation. We can claim that all translators rendered apocalyptic allusions carefully and meaningfully, hence, the question remains whether they identified them as allusions or simply attempted to translate the text as literally as possible.

The preferred strategies of literal translation or minimum change perhaps made it fairly challenging for the English reader to understand the connotation of New Jerusalem to which the text alluded. On the other hand, contemporary readers of the original may have faced the same difficulties, as the elimination of existing religion in the former Soviet Union created a huge gap in the cultural memory.

What is similar in all translations is that the translators, for the most part, judged that they did not need any additional guidance, thus avoiding the use of intra- and extratextual additions. Here, the question of subjectivity in predicting the readers' expertise and defining the criteria of what is "unfamiliar" arises. Cockrell's translation is the only one accompanied by endnotes that primarily explain historical facts, personalities and literary allusions (e.g. allusions to Pushkin's works).

Retranslations offer a unique opportunity for scholars to analyze translating tendencies over time. Even though it was impossible here to assess each translation comprehensively, owing to the number of available examples, some tendencies did emerge. The apocalyptic context of Bulgakov's City was successfully textualized in all three English translations. We found no omissions of allusions. Denotative meaning was usually transferred well in all translations, though Glenny's version demonstrates more contextual deviation from the original than the others. The question of whether translators recognized the original allusions remains open, as there are no textual signs for the recognition of allusions, i.e., deviations in spelling, lexis, grammar or style, 
quotation marks or any other "extra-allusive" devices, change in the length of the phrase, or use of an introductory phrase such as "as in the Book of Revelation".

\section{Works Cited}

Barratt, Andrew. "Apocalypse or Revelation? Man and History in Bulgakov's Belaya gvardiya." New Zealand Slavonic Journal, no. 1, 1985, pp. 105-31.

Ben-Porat, Ziva. "The poetics of literary allusion." PTL: A Journal for Descriptive Poetics and Theory of Literature, vol. 1, 1976, pp. 105-28.

Bulgakov, Mikhail. Belaya gvardia. Khudozhestvennaya literature, 1973.

Bulgakov, Mikhail. The White Guard. Translated by Michael Glenny, HarperCollins/Havill, 1971.

Bulgakov, Mikhail. The White Guard. Translated by Marian Schwartz, Yale University Press, 2008.

Bulgakov, Mikhail. The White Guard. Translated by Roger Cockrell, Alma Classics, 2012.

Leppihalme, Ritva. Culture Bumps: An Empirical Approach to the Translation of Allusions.

Multilingual Matters Ltd., 1997.

Leddy, Michael. "Limits of allusion.” British Journal of Aesthetics, vol. 32, no. 2, 1992, pp. 110-22.

Pasco, Allan H. Allusion: A Literary Graft. University of Toronto Press, 1994.

Perri, Carmela. "On alluding." Poetics, vol. 7, 1978, pp. 289-307.

Petrovsky, Miran. Master I gorod: Kievskije konteksty Mihaila Bulgakova. Duh i Litera, 2001.

Pucci, Joseph. The Full-knowing Reader: Allusion and the Power of the Reader in the Western L iterary Tradition. Yale University Press, 1998.

Sokolov, Boris V. Rasshifrovannaya Belaya gvardiya: Tainy Bulgakova. Litagent, Jauza, 2003.

Stewart, Susan. "The Pickpocket: A Study in Tradition and Allusion." Modern Language Notes, vol. 95, no. 5, 1980, pp. 1127-54, www.jstor.org/stable/pdf/2906486.pdf?seq=1. Accessed 19 Sept. 2018

The Book of Revelation: A New Translation of the Apocalypse. Translated by John Bertram Philips, The Macmillan Company, 1957. 
[1] Critics and literary historians have long since discovered the prototypes of virtually all the characters in The White Guard, even the most peripheral ones, as well as all the events from Bulgakov's life that are reflected in the novel, down to even the most marginal (Sokolov 7-15)

[2] The Russian forces, who became known as the Whites, fought against the Red Army in the Civil War from 1918 to 1921 . Their military arm was known as the White Army, or the White Guard.

[3] Turbin was the name of Bulgakov's grandmother.

[4] The same intertextual figures occur in Bulgakov's later works, always accompanied by the sensation of disaster, fear, and insanity. In the introductory and concluding chapters of The White Guard, Bulgakov uses direct quotes from the Book of Revelation, which signify the importance of this pre-text for the narrative. The eschatological and apocalyptic atmosphere of Bulgakov's works was reflective of his own experience. Born in 1891, Bulgakov witnessed the horrors of the Bolshevik revolution and Russian Civil War in Russia, which he comprehended as the realization of apocalyptic prophecy.

[5] One of the novel's epigraphs is also from the Book of Revelation.

[6] It was impossible to find out which translation of The Book of Revelation (if any) the translators used. We chose Phillip's translation from 1957 as it was published before Glenny's translation and is also considered one of the most popular translations. We assumed Glenny and perhaps other translators might have used it.

[7] Among numerous other sources, the meaning of the Book of Revelation in The White Guard is thoroughly explored in: M. Petrovsky (2001), Master I gorod. Kievskije konteksty Mihaila Bulgakova; B. Gasparov (1994), Novyj Zavet v proizvedeniah M. A. Bulgakova; and J. Jablokov (2001), Khudozhestvennyij Mir Mihaila Bulgakova. As for the general western critical trend, The White Guard is a much less explored work than The Master and Margarita, bemoaned in 1985 by Andrew Barratt, who wonders at the persistence of Belaya gvardiya's "double eclipse" (Barratt 105). Hence, we were only able to find three works that cover the meaning of the apocalyptic prophecy in The White Guard: A. Barratt (1985), "Apocalypse or Revelation? Man and History in 
Bulgakov's Belaya gvardiya"; E. Proffer (1972), The Major Works of Mikhail Bulgakov; and D. L. Bethea (1989), Apocalypse in Modern Russian Fiction.

[8] When the apocalyptic prophecy first occurs in The White Guard, it is in a dialogue between Alexey Turbin and the priest, who quotes from The Book of Revelation. Direct quoting from the Book of Revelation also occurs at the end of the novel, enveloping the novel in apocalyptic prophecy.

[9] Gardens also play an important role in depicting the City's topography as they adjoin both the Upper and the Lower City.

\section{cc) (i) () $९$}

Creative Commons Attribution-NonCommercial-NoDerivatives 4.0 International License 